\title{
The Relation between Religion and Science in Decree of the Indonesian Ulema Council in a Pandemic
}

\author{
Nazaruddin Latif \\ Universitas Aisyiyah Surakarta \\ nazar_faruqi@yahoo.com \\ Irma Mustika Sari \\ Universitas Aisyiyah Surakarta
}

DOI: 10.23917 /jtl.v2i2.12598

\begin{tabular}{ll}
\hline $\begin{array}{l}\text { Submission } \\
\text { Track: }\end{array}$ & ABSTRACT \\
Received: & $\begin{array}{l}\text { This paper examines the relation between religion and science } \\
\text { in Jecrees issued by the Indonesian Ulema Council in the field } \\
\text { of religion, particularly regarding the implementation of } \\
\text { worship for Muslims in Indonesia. The Indonesian Ulama }\end{array}$ \\
$\begin{array}{l}\text { Final Revision: } \\
\text { Council has issued a decree which not only prioritizes the an } \\
\text { sich religious approach but is also based on the results found } \\
\text { by scientists and researchers who are concerned about } \\
\text { studying the COVID-19 pandemic. Therefore, this paper } \\
\text { looks at the decree of the Indonesian Ulema Council based on } \\
\text { available online: }\end{array}$ & $\begin{array}{l}\text { a bibliographic approach by making this decree as the main } \\
\text { source. As a result, the decree issued by the Indonesian Ulema } \\
\text { Council has implicitly linked religion and science. }\end{array}$ \\
Corresponding & Keyword: Indonesian Ulema Council, Decree, Religion \\
Author: & and Science \\
Nazaruddin Latif & nazar_faruqi@yahoo.com
\end{tabular}

\section{INTRODUCTION}

The pandemic era presents serious problems in aspects of life, including the practice of implementing worship for Muslims. The product of Islamic law (fiqh), which is the ijtihad of the previous ulema and serves as a guide for worship for Muslims, is inevitably reviewed to be formulated in order to provide solutions to the practice of worship during the pandemic.

Mutholingah and Zamzami revealed a re-examination of Islamic laws and Islamic legal philosophy (ushul fiqh) due to aspects of life that develop as a result of human and cultural development (Mutholingah et al., 2018). The pandemic era which requires preventive action 
by carrying out social distancing, wearing masks and other anticipatory measures has changed the order of human social life. Including the practice of worship, especially prayers are still carried out with the consideration of prioritizing the aspect of prevention.

In this context, reconsideration as part of ijtihad needs to be carried out, and vice versa, it cannot remain totally with the old legal product even though the conditions are different. Quoting Auda's opinion, law must be flexible along with social life, and vice versa, law cannot be applied statically and rigidly (Auda: 2008). Therefore, problems in social life continue to develop along with legal consequences, as well as consequences in other fields that must be faced. It is important to note that in conducting a review of legal products, including Islamic law products, it is carried out with the perspective of various disciplines (multidisciplinary) (Mutholingah et al., 2018).

In the study of Islamic legal philosophy, maqashid shari'ah method has long been introduced which was actually formulated by the ulema of the classical period, namely Imam al-Juwaini (Wahyudi: 2006). However, because its use is flexible, maqashid shari'ah can be used throughout the ages, even though the context of social life continues to develop. In the contemporary era, the use of a multidisciplinary approach is very important to provide solutions to society's problems (Auda: 2008). The practice is to issue religious decrees, especially those related to Muslim worship in the pandemic era.

decrees issued by an authoritative institution such as the Indonesian Ulema Council can be categorized as fiqh. Borrowing from el-Fadl, religious decrees are the result of ijtihad carried out by the ulema, with all their abilities to formulate Islamic legal products - socalled fiqh - with the aim of implementing shari'ah which is the will of Allah SWT as a way for humans to do worship and draw close to Him (el-Fadl: 2003).

The Indonesian Ulema Council, through its authority in issuing decrees, cannot do so separately. Only relying on religious science without being supported by other knowledge generated through research serves as a supporting basis for the formulation of the decree. In the case of COVID-19, many scientists did research to uncover and identify and find effective ways to deal with its spread (Yuval Noah Harari, Slavoj Zizek, Arunhati Roy, Ethan Siegel, Ross Douthat, Hendry Marsh, Santiago Zabala, 2020). The results of research through the work of scientists and researchers are valuable information in the formulation of 
the decrees so that the Indonesian Ulema Council in issuing decrees is in line with the policies set by decision-making parties.

\section{METHOD}

This research is included in the bibliographical model because what it examines are religious decrees issued by the Indonesian Ulema Council in the pandemic era. The approach taken uses a critical philosophical approach, to reveal the meanings or objectives of the issuance of these religious decrees by revealing various scientific disciplines of knowledge.

\section{RESULTS AND DISCUSSIONS}

According to Syamsuddin, a systematic study of the relation between religion and science appeared at the beginning of the second half of the twentieth century. One of the important figures in charge of his emergence movement was Ian Barbour. Ian Barbour has a scientific capacity and an important role in the international arena, as evidenced by being frequently invited to various scientific forums by being a resource person in these forums (Syamsuddin: 2012). Thus, the study of science and religion has become a common theme studied in scientific forums as well as in religious forums, including in religious decrees.

\section{a. Decrees of the Indonesian Ulema Council in the Pandemic Era on Worship Procedures}

Since the pandemic was indicated to have entered Indonesia, the Indonesian Ulema Council as an authoritative institution has issued a decree on worship, as a guide for Muslims to carry out worship during the pandemic. The decree that has been issued by the Indonesian Ulema Council is decree number 14 of 2020, regarding the implementation of worship in the situation of the COVID-19 outbreak.

As a consideration in the decree, four points are mentioned, among others: because of the COVID-19 outbreak that has spread in Indonesia, the status of the pandemic that has been declared by the WHO international organization, the importance of religious-based measures to prevent and overcome, and the importance of issuing a decree (Ulama, 2020). 
Because with regard to decrees on worship, the foundation is based on the main source of religion as the basis. In addition to the four points mentioned above, the decree issued by the Indonesian Ulema Council also refers to sources in Islam, including:

1) Qur'an

In taking verses in the Qur'an, it is more of a preventive and advice with an emphasis on efforts to understand the status of the COVID-19 pandemic from the Islamic perspective. Emphasis on efforts to understand the existence of a pandemic by quoting the Qur'anic verse illustrates that the decree of the Indonesian Ulema Council invites Muslims to accept this pandemic condition religiously while improving spiritual quality.

2) Al-Hadith

Likewise, the hadith quoted also puts forward the hadith that calls for preventive action. Preventive measures contained in the hadiths quoted provide the meaning of religion in carrying out worship while paying attention to health protocols that must be met. Historically, health protocols were taken from the methods taught by the Prophet Muhammad, according to the context of his life. In practice, the substance of the teachings to continue to take preventive actions taught by the Prophet Muhammad was implemented in the context of the implementation of worship in the midst of a pandemic.

3) Fiqh Rules

The rules used are related to the concept of rukhsah or relief found in Islam. By taking the rukhsah contained in the implementation of religious teachings, especially in worship, the worship that is carried out although practically is not as optimal as in normal conditions, but worship is still fulfilled. Thus, in carrying out worship, Muslims remain calm.

In addition to the three principles above, the decree of the Indonesian Ulema Council has also been given categories or groupings contained in the legal provisions in the decree (Ulama, 2020). These categories include:

1) Emphasizing the obligation to each community to maintain their own health, by paying attention to health and avoiding things that have the potential to damage health. This 
obligation is emphasized as an effort to fulfill five points in religious matters (aldaruriyat al-khams).

2) Emphasizing on people who have been exposed to the virus to isolate themselves so as to avoid the possibility of transmitting them to others. Meanwhile, the implementation of worship by taking special rituals of worship which is obligatory to be carried out, while sunnah worship is better not done first.

3) Meanwhile, people who are in good health, but it is not known whether they have been exposed or not, keep themselves and pay attention to health protocols.

\section{b. Religious and Scientific Approaches}

Epistemologically, religion and science are two different entities. Science puts forward a rational and empirical approach, while religion puts forward an intuitive approach (Syarif, 2014). However, these differences do not rule out the possibility that religion and science are linked and linked to solve contemporary problems, including solving religious problems in the midst of a pandemic.

The religious and scientific approach is not explicitly stated in the decree of the Indonesian Ulema Council. However, by looking at the decree of the Indonesian Ulema Council substantially the religious and scientific approaches are included in it. The relation between religion and science in the formulation of the decree of the Indonesian Ulema Council is seen in its content which is in accordance with the in-depth study of experts and researchers who conducted a study on the COVID-19 pandemic. This conformity can be seen in the Indonesian Ulema Council appeal which states the recommendation to Muslims to comply with health protocols. Even the Indonesian Ulema Council recommendation obliges Muslims to support and obey government policies that isolate and treat people infected with the virus, as a form of prevention (Ulama, 2020).

The recommendations given by the Indonesian Ulema Council are a form of appeal based on the relation between religion and science. The relations and connections of religion and science embodied in the decree do not have to be done by mixing or forcing them to become one, but by bringing them together with the aim of building constructive and contributive relationships. The results found by scientists and researchers are sufficient as a basis for consideration in determining the decree to be issued. 
The acceptance of the Indonesian Ulema Council in making the findings of scientists and researchers as a basis is based on the openness of Islamic teachings in accepting modern science, including in responding to the COVID-19 pandemic. Quotations of Qur'anic verses and hadiths that are thematically understood dynamically in relation to the pandemic, then supported by fiqhiyah principles imply that the issuance of this decree cannot be done separately, only using the religious approach an sich without considering the scientific approach.

By considering this scientific approach, the decree of the Indonesian Ulema Council implicitly includes a multi-perspective approach as offered by Islamic jurists such as Jasser Auda (Auda: 2008). Thus, the decree of the Indonesian Ulema Council has met the criteria as a decree based on the integration of religion and science.

\section{CONCLUSION}

Based on the study that has been done above, it can be concluded that the Indonesian Ulema Council in issuing decree has attempted to link religious studies with science. Although the decree does not explicitly state the involvement of science, the openness of the Indonesian Ulema Council by using government appeals based on the findings of experts and researchers has illustrated this relation.

\section{BIBLIOGRAPHY}

Jasser Auda, Maqashid al-Syari'ah As Philosophy Of Islamic Law A Systemes Approach, London-Washington, (IIT: 2008).

Khaled M. Abou el-Fadl, Atas Nama Tuhan: Dari Fikih Otoriter ke Fikih Otoritatif, Jakarta, (Serambi: 2003).

Wahyudi, Yudian, Ushul Fikih Versus Hermeneutika: Membaca Islam Dari Kanada Dan Amerika, Yogyakarta, (Nawesea Press: 2006).

Syamsuddin, Ach Maimun, Integrasi Multidimensi Agama \& Sains: Analisis Sains Islam AlAttas dan Mehdi Golshani, Yogyakarta (IRCISoD: 2012).

Maqin, Khairil, dkk, Wabah, Sains Dan Politik, Yogyakarta (Antinomi: 2020).

Mutholingah, S., Al, A., Malang, H., Zamzami, R., Al, A., \& Malang, H. (2018). Siti Mutholingah | 90. 2, 90-112.

Syarif, E. (2014). Pergulatan Sains dan Agama. Refleksi, 13(5), 641-654. https://doi.org/10.15408/ref.v13i5.917

Yuval Noah Harari, Slavoj Zizek, Arunhati Roy, Ethan Siegel, Ross Douthat, Hendry Marsh, Santiago Zabala, E. Y. (2020). Wabah, sains, dan politik. https://antinomi.org 
Journal of Transcendental Law Vol. 02, No. 2, 2020, pp. 129-135

p-ISSN: 2714-9676 ; e-ISSN : 2714-965X http://journals.ums.ac.id/index.php/jtl/article/view/12598

Ulama, K. F. M. (2020). Penyelenggaran Ibadah dalam Situasi terjadi Wabah COVID-19. Mui, 14, 1-10. 